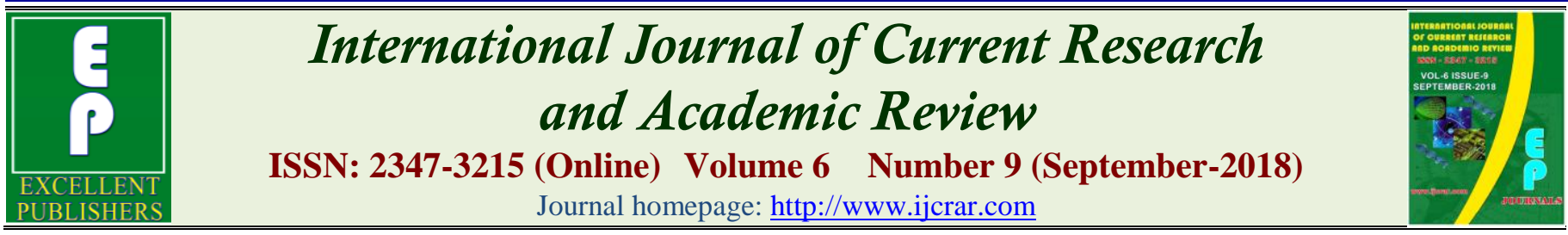

doi: https://doi.org/10.20546/ijcrar.2018.609.004

\title{
Technical Methodology for an Integrated System of Quality, Safety and Environment Management in the Hospital Nuclear Medicine Unit, Teodoro Maldonado Carbo De Guayaquil-Ecuador
}

\author{
Carlos Enrique Novillo Yaguarshungo ${ }^{1}$, Ángel Rigoberto Guamán Mendoza², \\ Jacinto Eduardo Villota Moscoso ${ }^{3}$ and José Luis Gavidia García ${ }^{* *}$
}

\author{
${ }^{1}$ Ingeniero en Mantenimiento, Magister en Gestión Industrial y Sistemas Productivos, Docente de la Escuela Superior \\ Politécnica de Chimborazo (2013-2017) Ecuador \\ ${ }^{2}$ Ingeniero Industrial, Magister en Docencia Universitaria e Investigación Educativa, Magister en Seguridad e \\ Higiene Industrial y Ambiental, Vice Decano de la Facultad de Mecánica ESPOCH, Docente de la Escuela Superior \\ Politécnica de Chimborazo - Ecuador \\ ${ }^{3}$ Ingeniero Industrial, Magister en Docencia Universitaria e Investigación Educativa, Docente de la Escuela Superior \\ Politécnica de Chimborazo, Riobamba, Ecuador \\ ${ }^{4}$ Ingeniero Industrial, Magister en Gestión Industrial y Sistemas Productivos, Docente de la Escuela Superior \\ Politécnica de Chimborazo (2013-2018) Ecuador
}

*Corresponding author

\section{Abstract}

The Nuclear Medicine Technical Unit of the Dr. Teodoro Maldonado Carbo Hospital in the city of Guayaquil, provides the service of treatment to patients with thyroid pathologies, using radioactive elements, in view of the relevance of the procedure, a technical methodology is proposed for a integrated quality, safety and environmental management system in this unit, which it allows to identify the existing deficiencies among the activities, processes and procedures that are currently carried out, in correspondence with the fulfillment of the clauses established in the ISO 9001: 2008, ISO 140001 and OSHAS 18001 Standards with the purpose of establishing the necessary actions to improve the safety and quality in the service, obtaining a beneficial result for both the hospital's internal staff and patients. Through the application of the Chi square test, it was generally determined that the unit meets $62.53 \%$ with the Integrated Quality, Safety and Environmental Management System, while $37.47 \%$ does not comply.
\end{abstract}

\section{Article Info}

Accepted: 25 August 2018

Available Online: 20 September 2018

\section{Keywords}

Nuclear Medicine, Quality of Service, Audit Processes, Pathology, Thyroid, Radiological Protection, Imaging

\section{Introduction}

In various public and private hospitals that provide radiotherapy, imaging and X-rays, patients with thyroid diseases, among others, have a nuclear medicine unit, for which an integrated Quality Management design is essential, Safety and Environment, to carry out this activity efficiently, organized and controlled. The document is a fundamental tool to offer a quality service and safety, both to the hospital staff and to the patients, since the quality instruments have been designed according to the requirements demanded by ISO 9001: 2008, ISO 14001 and OSHAS 18001. Through the application of the quality management audit, proposed 
by the International Atomic Energy Agency (IAEA), it is intended to determine the degree of compliance of the different processes and procedures performed in the Nuclear Medicine unit against the requirements established by the International Regulation that governs medical services that use ionizing radiation as a therapeutic modality.

In the health sector, the IAEA has provided technical assistance in the field of nuclear medicine, with the aim of improving the clinical practice of the specialty through an effective management system that integrates quality management, safety and Ambient. In 2009, the IAEA published the document: "Quality management audits in nuclear medicine practices" (QUANUM), whose document has been designed in such a way that it can be applied to a variety of economic circumstances, and with the purpose to obtain constant improvements in the effectiveness and efficiency of the service provided under the fulfillment of its quality policy and the satisfaction of its clients, under these principles in the present investigation the following objective was established: Evaluate the integrated system of quality management, safety and environment for the Nuclear Medicine Unit of the Hospital "Dr. Teodoro Maldonado Carbo "from the city of Guayaquil. (IAEA, International Atomic Energy Agency, 2009). The IAEA plays an important role in ensuring that the highest levels of safety are maintained when applying radiation techniques. This means protecting the personnel administering the procedures to avoid exposure to radioactivity, and ensuring that patients receive the correct dose.

Basically, the IAEA supports the holistic approach to public health, with the objective of enabling low and middle income countries, in particular, to establish comprehensive health care systems, with qualified personnel and adequate equipment, to offer a early detection, timely diagnosis and effective treatment of noncommunicable diseases, as well as palliative care.

\section{Materials and Methods}

\section{Equipment}

The equipment for the development of the activities is shown in Figure 1, while in Table 1, the inventoried equipment is described: An Iodine gauge, which constitutes a system of thyroid uptake specifically designed for nuclear medicine, Two activimeters or dose calibrators, essential instruments for measuring the activity of radioisotopes used in diagnostic and therapeutic procedures. These devices provide an accurate measurement of the dose that is administered to the patient, ensuring that this dose is the same as that prescribed by the doctor, two radiation detectors, a detector with pancake type probe, suitable for measuring with greater degree of precision and Accuracy levels of radioactive contamination in the different areas of the facility, and a cart conveyor elements.

An audit of compliance and maintenance of the equipment used in the nuclear medicine unit was performed, based on the Integrated Quality Management System (IACS), to identify the areas under study and application of the improvement, being determined; Strategies and Policies of Administration and Management, Development of Human Resources, Compliance in Irradiation, Regulation and Safety, Radiological Protection of the Patient, Evaluation and Guarantee of the Quality System, Quality Control for the Imaging Equipment, General Aspects - Clinical Services, General Aspects - Therapy Service with Iodine 131, and Hospital Radiopharmacy. The same ones that were analyzed once the compliance percentage was obtained, this process was carried out using the chi square test as a statistical method to check the hypothesis.

In the nuclear medicine services, an effective management system that integrates the management of Quality, Safety and Environment is essential. The IAEA has established requirements and safety guidelines on quality management systems that should be met in the facilities. Such systems are maintained with the purpose of continuously improving the efficacy and efficiency of the service, in addition, the expectations of the quality policy must be met and patient satisfaction must be met (IAEA, 2009). Under this perspective, this chapter develops the proposed methodology for conducting the quality management audit in the Nuclear Medicine unit of the Dr. Teodoro Maldonado Carbo Hospital in the city of Guayaquil.

\section{Methods}

\section{Historical Method - Logical}

Previous bibliographic research on management in the nuclear medicine service on a global and national scale, seeks to integrate the planning and design of a quality, safety and environmental management system through the application of the Standards ISO 9001: 2008, ISO 14001 and OSHAS 18001. 


\section{Analysis and Synthesis}

With the analysis of the current situation of the Nuclear Medicine unit and the quality assessment established in the audit, it is possible to detect non-conformities and plan and design possible solutions, taking as a reference the continuous improvement of the processes and procedures.

\section{Systemic method}

Through this method, the relationship of the clinical, physical, technical and radiological safety processes and procedures and their application in patient care is evidenced.

\section{Method of Observation Scientific}

This method allows transform empirical scientific knowledge from the problem, objectives, rationale and forms the basis of Conceptual Theoretical Framework.

Consultation with experts in the field: The applied research techniques are related to surveys and interviews with the authorities and personnel that provide their professional services in the Nuclear Medicine unit, obtaining the information based on their expertise that will significantly contribute to the investigation.

\section{Data collection instrument}

The instrument designed for data collection in this research work is a questionnaire that contains questions about the quality of nuclear medicine services, which has been proposed by the IAEA through the QUANUM. The application of the questionnaire allows verifying the level of compliance with the processes carried out in the unit. Table 2 shows the qualification criteria.

\section{Strategies and policies}

Compliance with the strategies and policies described in Table 3, address to achieve patient satisfaction in the service provided.

This same procedure applies to all the aspects that make up this system.

\section{Results and Discussion}

Through the field work carried out in the Nuclear Medicine Unit of the Dr. Teodoro Maldonado Carbo
Hospital, the tables were graded with the help of experts in the field. To this end, instruments were designed for the collection of data that contain questions about the quality of the nuclear medicine service, both to the hospital staff and to patients.

The application of the questionnaire allowed verifying the level of compliance with the processes carried out in this unit.

In this way, it was possible to partially determine, in terms of strategies and policies, compliance with; $70.80 \%$, in Administration and Management $70.0 \%$, Irradiation $84.0 \%$, Radiation protection of the patient $75.00 \%$, Evaluation of guarantees of the quality system $36.70 \%$, Control of imaging equipment $0.00 \%$, Computer systems and handling $0.00 \%$, Acceptance tests $0.00 \%$, Clinical services $35.70 \%$, Therapy services with iodine 131, 85.00\%, and Hospital radiopharmacy $50.00 \%$, concluding that the control of Quality, handling systems and acceptance tests are not $100 \%$ met.

Next, the results are presented with the respective analysis for what has been described.

\section{Analysis}

In the case of Table 3. Strategies and policies of nuclear medicine, the percentage of compliance corresponds to $70.8 \%$. The identified findings are detailed below:

There is little coordination with radiology, oncology and cardiology due to the lack of equipment for studies and diagnoses using radiopharmaceuticals.

The range of diagnostic services is not appropriate according to the size and scope of the Hospital's clinical service.

The Unit does not provide satellite services.

\section{Strategies and Policies Nuclear Medicine}

In the Nuclear Medicine Strategies and Policies, the percentage of compliance corresponds to $70.8 \%$ : due to; There is little coordination with radiology, oncology and cardiology due to lack of equipment for diagnostic studies using radiopharmaceuticals. The range of diagnostic services is not appropriate according to the size and scope of the Hospital's clinical service. The Unit does not provide satellite services. 


\section{Administration and management}

In the Administration and Management, the percentage of compliance corresponds to $70.0 \%$ determined in: Periodic examinations of the work procedures used in the reception area are not carried out, the application forms are incomplete, in addition, there is no written evidence of the procedure, quality factors or indicators are not established to meet requests in time of maximum demand, applications are not examined by a specialized nuclear medicine doctor, standard operating procedures are carried out at the level of operators and competent professionals, without written evidence, the periodic examination of a registered pharmacist is applied, because the diagnostic service of nuclear medicine is not provided, using radiopharmaceuticals, and no mechanisms have been established to treat defects or deficiencies.

\section{Human resources development}

In the development of human resources, the percentage of compliance corresponds to $55.6 \%$.

The identified findings are detailed in: A system of continuous professional education and development is established, however, it is moderately met, there are no programs developed for the training of technologists, no instruments are designed for the objective supervision of training, it is not carried out periodic examinations to determine the training needs, the personnel is trained in security and radiological protection, the professionals of the Unit do not have access to web teaching, updated books and / or periodicals.

\section{Compliance in terms of irradiation, regulation and safety}

In compliance with irradiation, regulation and safety, the compliance percentage corresponds to $84.0 \%$.

The identified findings are: Documentation confirming that officials have read and understood local regulations is not shown, facilities for drug administration are not adequate, there is no evidence of detailed procedures for the handling of specimens, no written evidence Periodic checks for radioactive waste in relation to the established limits.

\section{Radiological protection of the patient}

In radiological protection of the patient, the compliance percentage corresponds to $75.0 \%$.

The identified findings are: Documentation is not shown for verification procedures of which the doses do not exceed the reference values recorded in the BSS or local regulations,

There are no documented procedures to minimize the registry of mismanagement of radiopharmaceuticals, there are no documented procedures to minimize the recording of multiple exposures.

\section{Evaluation and guarantee of the quality system}

In radiological protection of the patient, the percentage of compliance corresponds to $36.7 \%$.

The identified findings are: The unit does not have a quality manual, does not perform self-evaluations and quality audits, the unit does not have a system to evaluate patient satisfaction and degree of satisfaction of referring physicians, no procedures are established to handle cases of non-compliance, there are no mechanisms to supervise data that guarantee quality improvement, technical specifications for equipment purchase are partially established, specifications are not established to carry out equipment acceptance tests, there is no guarantee program for quality, the results of the quality management program are not evaluated, recorded and examined, procedures are not established to guarantee that equipment or materials that do not pass the quality tests are not used,No maintenance, repair or replacement plans are established for the equipment, the Unit does not participate in external quality management programs.

\section{Quality control of the imaging equipment}

In the quality control of imaging equipment, the compliance percentage corresponds to $0.0 \%$, since the unit does not have the equipment to carry out studies and diagnoses using radiopharmaceuticals.

Patients who come to the institution for this type of study are referred to external provider, therefore, in the assignment of the rating in Table 2 has been considered the NA column (Not applicable); however, it is important to pay attention to the items in order to maintain the relevant documentation in case the implementation of the imaging equipment for nuclear medicine is managed.

Table.1 Equipment of the Nuclear Medicine unit 


\begin{tabular}{|l|l|l|l|}
\hline FIRST NAME & SERIAL NUMIBER & BRAND & MODEL \\
\hline Iodine sensor & $187-295$ & Atomlab & 900 \\
\hline Activimeter & 645 & VICTORY & $32-061$ \\
\hline Activimeter & 93286053 & Atomlab & --------- \\
\hline Radiation detector & 42926 & SE-INTERNATIONAL & INSPECTOR USD \\
\hline Radiation detector & 70337 & SE-INTERNATIONAL & MONITOR 4 \\
\hline Detector with probe & 90912 & ATOMIC & 14c \\
\hline $\begin{array}{l}\text { Carrier cart of radioactive } \\
\text { elements }\end{array}$ & ------------ & ------------ & \\
\hline
\end{tabular}

Source: Nuclear Medicine unit files Teams.

Table.2 Qualification criteria for the audit

\begin{tabular}{|l|l|c|}
\hline ACRONYM & \multicolumn{1}{|c|}{ GRADING CRITERIA } & WEIGHT (\%) \\
\hline NA & $\begin{array}{l}\text { Not applicable (in accordance with the exclusion } \\
\text { parameters of the established Rules) }\end{array}$ & $0 \%$ \\
\hline PC & $\begin{array}{l}\text { Little compliance (It is applicable, it is done, but not in } \\
\text { accordance with the established norms, without evidence } \\
\text { and without records) }\end{array}$ & $\begin{array}{l}\text { Medium compliance (It is applicable, it is done and it is } \\
\text { moderately compliant with the established norms, there is } \\
\text { little evidence and partial records) }\end{array}$ \\
\hline MC & $\begin{array}{l}\text { High compliance (it is applicable, in accordance with the } \\
\text { established norms, with results, records and evidences) }\end{array}$ & $50 \%$ \\
\hline AC & \multicolumn{1}{|c|}{$100 \%$} \\
\hline
\end{tabular}

Made by: José Gavidia, 2017

Table.3 Nuclear medicine strategies and policies

\begin{tabular}{|c|c|c|c|c|c|c|}
\hline No & COMPONENTS & CLASS & $\begin{array}{c}\mathrm{PC} \\
25 \%\end{array}$ & $\begin{array}{l}\mathrm{MC} \\
\mathbf{5 0 \%}\end{array}$ & $\begin{array}{c}\mathrm{AC} \\
100 \%\end{array}$ & $\begin{array}{l}\text { NA } \\
\mathbf{0} \%\end{array}$ \\
\hline 1.1 .1$. & Is the unit governed by specific objectives drawn at the national level? & $\mathrm{B}$ & & & 1 & \\
\hline 1.1 .2$. & Is the unit governed by specific objectives set within the hospital? & $\mathrm{B}$ & & & 1 & \\
\hline 1.1 .3$. & Is there sufficient coordination with radiology, oncology and cardiology? & $\mathrm{C}$ & 1 & & & \\
\hline 1.1 .4 & Does the unit have a written organizational chart? It's updated? & $\mathrm{B}$ & & & 1 & \\
\hline 1.1 .5 & $\begin{array}{l}\text { Does the organization chart indicate lines of communication and } \\
\text { authority? }\end{array}$ & $\overline{\mathrm{B}}$ & & & $\overline{1}$ & \\
\hline 1.1.6. & $\begin{array}{l}\text { Is the range of therapeutic and diagnostic services appropriate to the size } \\
\text { and scope of the hospital's clinical service? }\end{array}$ & B & 1 & & & \\
\hline 1.1 .7$. & $\begin{array}{l}\text { Is the provision of services for urgent requests included among the } \\
\text { objectives of the unit? }\end{array}$ & B & & & 1 & \\
\hline 1.1 .8 & $\begin{array}{l}\text { Are the objectives and objectives of the unit included in the provision } \\
\text { and maintenance of high quality care through audits and quality controls } \\
\text { from the clinical point of view? }\end{array}$ & A & 1 & & & \\
\hline 1.1.9. & Does the nuclear medicine unit have an activity plan? & $\mathrm{B}$ & & & 1 & \\
\hline 1.1 .10 . & $\begin{array}{l}\text { Does the unit have a strategy regarding the advances recorded in } \\
\text { diagnosis and treatment? }\end{array}$ & B & & 1 & & \\
\hline 1.1 .11$. & $\begin{array}{l}\text { If the hospital does not provide a full range of nuclear medicine services, } \\
\text { do you have strategies or policies to refer patients to other centers? }\end{array}$ & B & & & 1 & \\
\hline 1.1 .12 . & $\begin{array}{l}\text { In the case of providing satellite services (technical and clinical support } \\
\text { to other hospitals) is responsibility defined in the provision of these } \\
\text { services? }\end{array}$ & B & 1 & & & \\
\hline \multirow{2}{*}{\multicolumn{3}{|c|}{$\begin{array}{r}\text { SUM } \\
\text { PERCENTAGE }(\%)\end{array}$}} & 4 & 1 & 7 & 0 \\
\hline & & & $8.3 \%$ & $4.2 \%$ & $58.3 \%$ & $0.0 \%$ \\
\hline \multicolumn{3}{|c|}{ TOTAL COMPLIANCE } & \multicolumn{4}{|c|}{$70.8 \%$} \\
\hline
\end{tabular}

Made by: José Gavidia, 2017 
Table.4 Average compliance (in percentage) of the unit for the IACS

\begin{tabular}{|l|l|l|l|}
\hline No & First name & Fulfillment & $\begin{array}{l}\text { Non- } \\
\text { compliance }\end{array}$ \\
\hline 1 & Nuclear medicine strategies and policies & 70,80 & 29,20 \\
\hline 2 & Administration and management & 70,00 & 30,00 \\
\hline 3 & Human resources development & 55,60 & 44,40 \\
\hline 4 & $\begin{array}{l}\text { Compliance in terms of irradiation, } \\
\text { regulation and safety }\end{array}$ & 84,00 & 16,00 \\
\hline 5 & Radiological protection of the patient & 75,00 & 25,00 \\
\hline 6 & Evaluation and Quality System Guarantee & 36,70 & 63,30 \\
\hline 7 & Quality control for the imaging equipment & 0,00 & 100,00 \\
\hline 8 & Computer systems and data manipulation & 0,00 & 100,00 \\
\hline 9 & Acceptance Tests & 0,00 & 100,00 \\
\hline 10 & General aspects - clinical services & 35,70 & 64,30 \\
\hline 11 & $\begin{array}{l}\text { General Aspects - Iodine Therapy Service } \\
131\end{array}$ & 85,00 & 15.00 \\
\hline 12 & Hospital radiopharmacy. & 50,00 & 50,00 \\
\cline { 2 - 3 } AVERAGE & 62,53 & 37,47 \\
\hline
\end{tabular}

Made by: José Gavidia, 2017

Table.5 Degrees of freedom

\begin{tabular}{|l|}
\hline Gl. $=$ Degrees of Freedom \\
\hline Gl. $=(r-1)(K-1)=3$ \\
\hline $\mathrm{r}=$ No. of rows $=4$ \\
\hline K $=$ No. of columns $=2$ \\
\hline Critical value in table \\
\hline Nivel Sig. $=\mathbf{8 \%}$ \\
\hline
\end{tabular}

Made by: José Gavidia, 2017

Table.6 Critical values of the Chi square distribution

\begin{tabular}{c|rrrr}
\multirow{2}{*}{$\begin{array}{c}\text { Grados } \\
\text { de libertad, }\end{array}$} & \multicolumn{5}{|c}{ Area de cola derecha } \\
\cline { 2 - 5 } $\boldsymbol{g l}$ & $\mathbf{0 . 1 0}$ & \multicolumn{1}{|c}{0.05} & \multicolumn{1}{c}{$\mathbf{0 . 0 2}$} & \multicolumn{1}{c}{$\mathbf{0 . 0 1}$} \\
\hline 1 & 2.706 & 3.841 & 5.412 & 6.635 \\
2 & 4.605 & 5.991 & 7.824 & 9.210 \\
3 & 6.251 & 7.815 & 9.837 & 11.345 \\
4 & 7.779 & 9.488 & 11.668 & 13.277 \\
5 & 9.236 & 11.070 & 13.388 & 15.086 \\
& 10.645 & 12.592 & 15.033 & 16.812 \\
6 & 12.017 & 14.067 & 16.622 & 18.475 \\
7 & 13.362 & 15.507 & 18.168 & 20.090 \\
8 & 14.684 & 16.919 & 19.679 & 21.666 \\
9 & 15.987 & 18.307 & 21.161 & 23.209 \\
10 & 17.275 & 19.675 & 22.618 & 24.725 \\
11 & 18.549 & 21.026 & 24.054 & 26.217 \\
12 & 19.812 & 22.362 & 25.472 & 27.688 \\
13 & 21.064 & 23.685 & 26.873 & 29.141 \\
14 & 22.307 & 24.996 & 28.259 & 30.578 \\
15 & & & &
\end{tabular}

Source: (Mason, 2003) 
Table.7 Chi square fit test ()

\begin{tabular}{|c|c|c|c|c|c|}
\hline PROCESSES & Fo & $\mathrm{fe}$ & (fo-fe) & $(\mathrm{fo}-\mathrm{fe})^{\wedge} 2$ & $\left((\mathrm{fo}-\mathrm{fe})^{\wedge} 2\right) / \mathrm{fe}$ \\
\hline $\begin{array}{l}\text { NUCLEAR MEDICINE STRATEGIES } \\
\text { AND POLICIES }\end{array}$ & 70,8 & 62,53 & 8,27 & 68,3929 & 1,093761395 \\
\hline $\begin{array}{ll}\text { ADMINISTRATION } & \text { AND } \\
\text { MANAGEMENT } & \\
\end{array}$ & 70 & 62,53 & 7,47 & 55,8009 & 0,892386055 \\
\hline $\begin{array}{ll}\text { HUMAN } & \text { RESOURCES } \\
\text { DEVELOPMENT } & \\
\end{array}$ & 55,6 & 62,53 & $-6,93$ & 48,0249 & 0,768029746 \\
\hline $\begin{array}{l}\text { COMPLIANCE WITH REGARDING } \\
\text { IRRADIATION, REGULATION AND } \\
\text { SECURITY }\end{array}$ & 84 & 62,53 & 21,47 & 460,9609 & 7,371835919 \\
\hline $\begin{array}{l}\text { RADIOLOGICAL PROTECTION OF } \\
\text { THE PATIENT }\end{array}$ & 75 & 62,53 & 12,47 & 155,5009 & 2,486820726 \\
\hline $\begin{array}{l}\text { EVALUATION AND WARRANTY OF } \\
\text { THE QUALITY SYSTEM }\end{array}$ & 36,7 & 62,53 & $-25,83$ & 667,1889 & 10,66990085 \\
\hline $\begin{array}{lrcc}\text { QUALITY } & \text { CONTROL } & \text { FOR } & \text { THE } \\
\text { IMAGENOLGIA TEAM } & & \\
\end{array}$ & 0 & 0 & 0 & 0 & 0 \\
\hline ACCEPTANCE TESTS & 0 & 0 & 0 & 0 & 0 \\
\hline $\begin{array}{l}\text { COMPUTER SYSTEMS AND DATA } \\
\text { HANDLING }\end{array}$ & 0 & 0 & 0 & 0 & 0 \\
\hline $\begin{array}{lll}\text { GENERAL } & \text { ASPECTS } & \text { - CLINICAL } \\
\text { SERVICES } & & \\
\end{array}$ & 35,7 & 62,53 & $-26,83$ & 719,8489 & 11,51205661 \\
\hline $\begin{array}{lcl}\text { GENERAL ASPECTS } & - & \text { IODINE } \\
\text { THERAPY SERVICES } 131 & \\
\end{array}$ & 85 & 62,53 & 22,47 & 504,9009 & 8,074538621 \\
\hline HOSPITAL RADIOPHARMACY & 50 & 62,53 & $-12,53$ & 157,0009 & 2,510809212 \\
\hline
\end{tabular}

Made by: José Gavidia, 2017

Fig.3 Results that correspond to the percentage of compliance in each category

\begin{tabular}{|l|l|l|l|l|}
\hline Hospital radiopharmacy. & & & $50.00 \%$ & \\
\hline $\begin{array}{l}\text { General Aspects - Iodine Therapy } \\
\text { Service 131 }\end{array}$ & & & & $85.00 \%$ \\
\hline General aspects - clinical services & & $35.70 \%$ & & \\
\hline Acceptance Tests & $0.00 \%$ & & & \\
\hline $\begin{array}{l}\text { Computer Systems and data } \\
\text { manipulation }\end{array}$ & $0.00 \%$ & & & \\
\hline Quality control - imaging equipment & $0.00 \%$ & & & \\
\hline $\begin{array}{l}\text { Evaluation and Quality System } \\
\text { Guarantee }\end{array}$ & & $36.70 \%$ & & \\
\hline Radiological protection of the patient & & & & $75.00 \%$ \\
\hline $\begin{array}{l}\text { Compliance in matters of irradiation, } \\
\text { regulation and... }\end{array}$ & & & & \\
\hline Human resources development & & & $55.60 \%$ & \\
\hline Administration and management & & & & $70.00 \%$ \\
\hline Nuclear medicine strategies and policies & & & & \\
\hline
\end{tabular}

$0.00 \% 10.00 \% 20.00 \% 30.00 \%$ 40.00\% 50.00\% 60.00\% 70.00\% 80.00\% 90.00\%

Made by: José Gavidia, 2017 
Fig.1 Equipment. (a) Iodine sensor, (b) Chest protector, (c) Activimeter BIODEX, (d) radiation detectors, (e) Activimeter

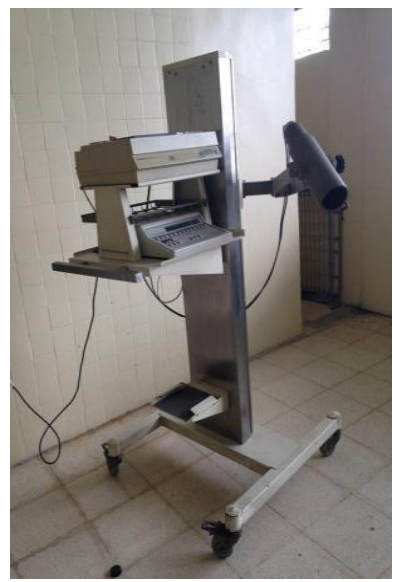

(a)

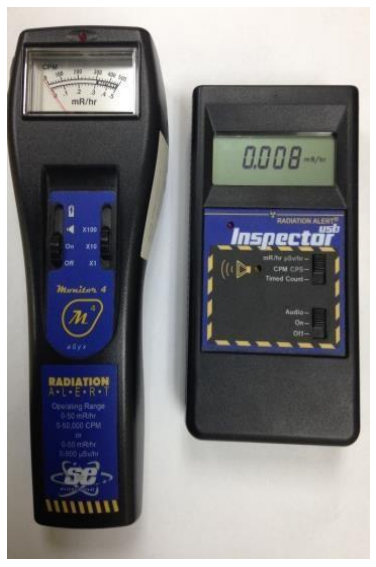

(c)

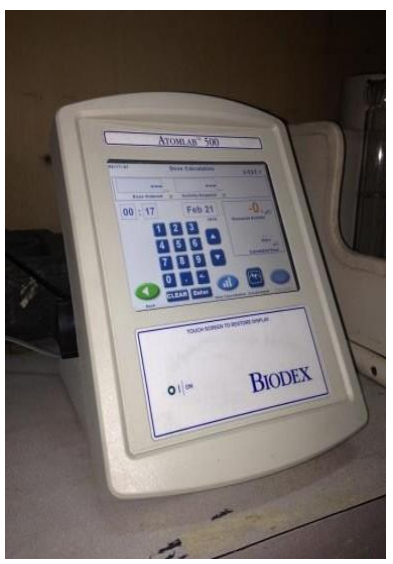

(b)

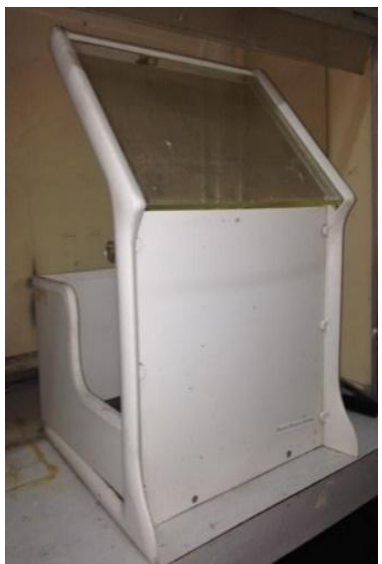

(d)

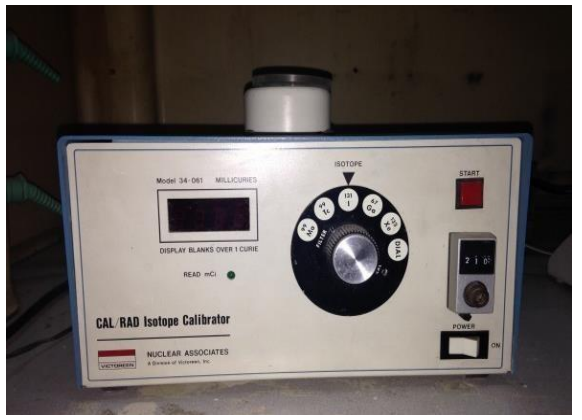

(e)

Source: Nuclear Medicine Unit 
Fig.2 Results obtained from Table 3. Strategies and Policies of Nuclear Medicine

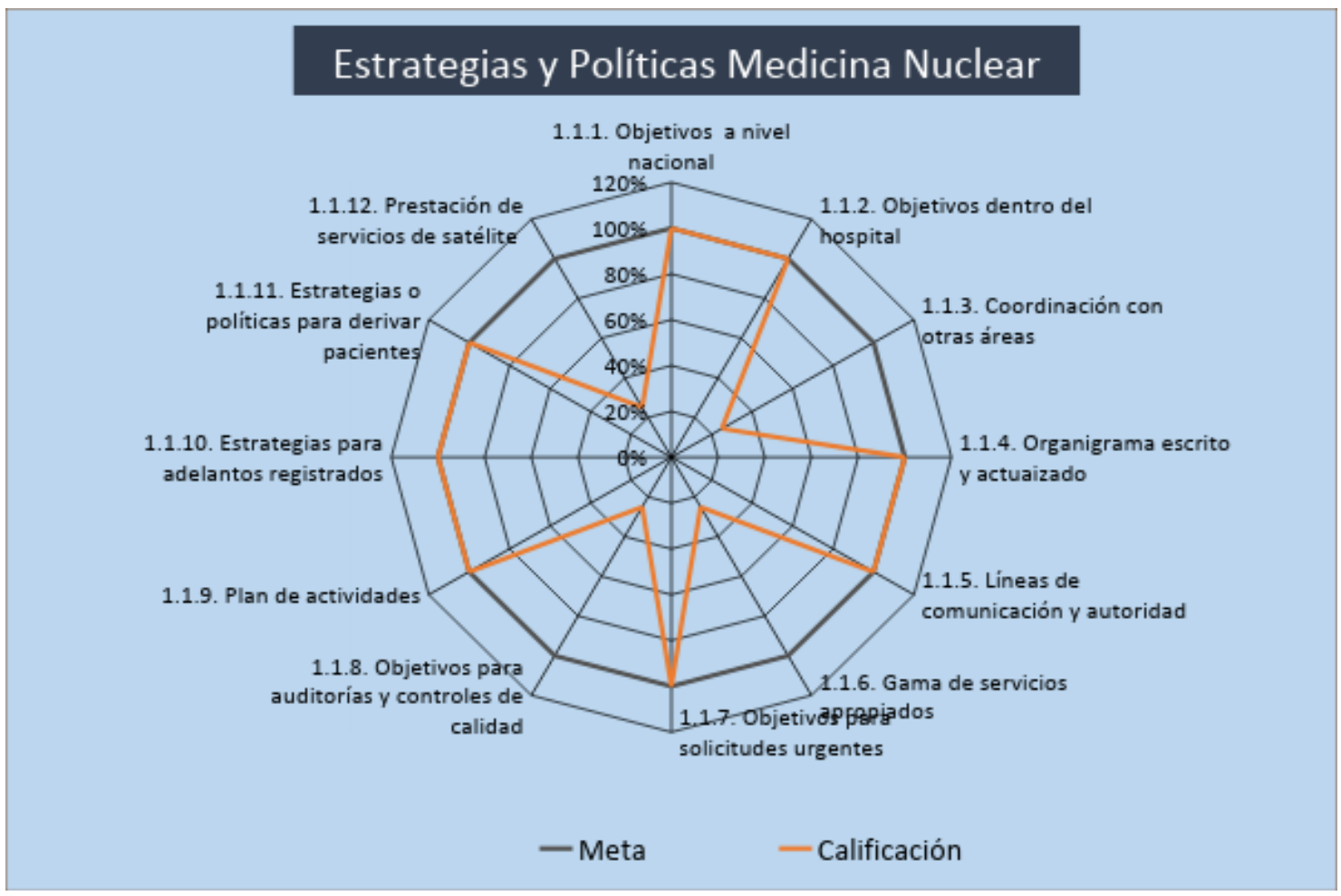

Made by: José Gavidia, 2017

\section{Computer systems and data manipulation}

In computer systems and data manipulation, the percentage of compliance corresponds to $0.0 \%$, since the unit does not have computer systems to perform diagnostic studies using radiopharmaceuticals, these computer systems are those used for the acquisition of images in nuclear medicine, basically analyzes the data, transforming them into color images that allow to identify affected areas of the human body and at the same time allows to review the functioning of the organs. Although the unit does not have the computer equipment to perform these types of procedures, it is important to pay attention to the requirements in order to prepare the ground for a future implementation.

\section{Acceptance Tests}

In the acceptance tests, the percentage of compliance corresponds to $0.0 \%$, since the unit has not acquired the equipment that requires performing this type of tests.

\section{General aspects - Clinical services}

In the General aspects - Clinical services, the percentage of compliance corresponds to $35.7 \%$, the identified findings are: Periodic examinations are not performed for the diagnostic care process, due to lack of equipment, the unit does not have a doctor to answer the questions of the patients, in the clinical case the questions are answered by the endocrinology doctors, the supervision of the patients is carried out when they remain in the unit, however, there is no written evidence of the procedure, in the unit there is no It has established policies for the care of pediatric nuclear medicine patients. No medical supervision is carried out in diagnostic studies, in the case of treatments, the respective supervision is carried out in terms of safety and radiological protection,

\section{General aspects - iodine therapy service}

In the General aspects - iodine therapy service 131, the compliance percentage corresponds to $85.0 \%$. The identified findings are:

The clinical indications for the requested therapy is not made by a doctor specialized in nuclear medicine, the radioactive dose has the consent of the physical doctor, however, it is necessary the presence of the doctor specialized in nuclear medicine, the disposition of rooms for the internment of patients is not appropriate and are insufficient for the existing demand. 


\section{Hospital radiopharmacy}

In hospital radiopharmacy, the compliance percentage corresponds to $50.0 \%$. The identified findings are: The unit does not have written training manuals for officials of the radiopharmacy category, the radiopharmacy room is not properly shielded, the unit does not work with radioactive iodine capsules, the extractor hood for manipulation of radioactive iodine is adequate, however, the respective maintenance is not performed, the procedures are performed under aseptic conditions, however, no written documentation is evidenced, the iodine handling room 131 has moderately adequate shielding, no documentation is evidenced written audits in the administration of radiopharmaceuticals, there are no written procedures for products that do not meet the required standards, adequate procedures are carried out for the disposal of radioactive and non-radioactive waste, however, no written documentation is evidenced.

\section{Calculation}

To determine the Chi square

The degrees of freedom correspond to the following formula

For the analysis a level of significance of 0.05 or $5 \%$ is taken $\mathrm{P}=1$ - (level of significance)

$\mathrm{P}=1-(0,05) \mathrm{P}=0,95$

With the value of $\mathrm{p}=0.95$ and the value $\mathrm{v}=8$ of the degrees of significance, a theoretical value of 15.50 is obtained in the distribution table of Chi squared.

\section{Calculations}

$\chi^{2}=\sum_{i=1}^{k} \frac{\left(O_{i}-E_{i}\right)^{2}}{E_{i}}$.

With the obtained data, the Chi square formula is applied, to check the validity of the hypothesis: Taking into account the level of significance that is $5 \%$, the theoretical chi-square will be equal to 15,507 . Having obtained a Chi square of 45,38013913 and being greater than the theoretical Chi square, the null hypothesis is annulled and the alternative hypothesis is accepted. In summary, the percentage of total compliance of the Nuclear Medicine unit of the Dr. Teodoro Hospital Maldonado Carbo, in the research carried out corresponds to $62.53 \%$.
Because the procedures that relate to the items described in them, are not performed in the Unit. Table 7 shows the compliance percentage, while graph 21 shows the results schematically.

The situational analysis of the Nuclear Medicine Unit, allows identifying the existing deficiencies among the activities, processes and procedures that are currently carried out, in correspondence with the compliance with the clauses established in the ISO 9001: 2008, ISO 140001 and OSHAS Standards. 18001 in order to establish the necessary actions to improve the quality of the Service.

The evaluation of the quality, safety and environment applied to the Nuclear Medicine Unit through the application of the QUANTEC Audit proposed by the IAEA, allowed to determine a compliance level of $62.53 \%$ at the date of the development of the present investigation.

The identification of the improvement needs in the quality documentation of the processes and procedures that are developed in the nuclear medicine unit, allows to take the necessary preventive and / or corrective actions so that the Integrated System of Management of Quality, Safety and Environment, complying with the continuous improvement approach.

The methodology designed in the design proposal of the Integrated Quality, Safety and Environmental Management System will contribute to: improving the organization of work, improving the quality of the service, considering a patient-oriented approach, reducing the number of adverse effects, nonconformities, technical breakdowns and repair costs, increase the safety of both the patient and staff and the strengthening of teamwork.

\section{Recommendations}

Once the Management System for Quality, Safety and Environment has been designed, the implementation must be carried out with the active participation and commitment of all the professionals working in the Unit, in such a way that the quality of the service is guaranteed.

Manage unconditional support before the authorities for the need of economic and human resources for the implementation of the Quality, Safety and Environment Management System in the Nuclear Medicine Unit 
Establish and comply with an annual plan of internal audits to identify non-conformities and implement improvement plans that allow for their resolution.

Establish and comply with a training plan that motivates professionals in achieving better results.

Take into consideration that the process of implementing a management system based on compliance with the requirements of ISO 9001: 2008, ISO 14001 and OSHAS 18001 is a continuous and cyclical process.

\section{References}

Arias, C., Borras, C., Castellanos Robayo, J., de Miquel, MA, Hanson Gerald, Khatib, S., \& Skvarca, J. (1999). Organization, development, quality assurance and radioprotection in radiology, imaging and radiotherapy services. Argentina: Pan American Health Organization (PAHO).

Barrera, María. (2011). Financing, Regulation and Control in Latin America: More quality and rights in Health. Santiago: Publications Superintendence of Health.

Bernal, C. (2010). Investigation methodology. Bogotá: Pearson. Besterfield, D. (2009). Quality Control Illinois: Prentice Hall. INC.

Camisón, C., Cruz, S., \& González, T. (2006). Quality management: concepts, approaches, models and systems. Madrid: Pearson Educación SA

Chiavenato, I. (2002). Human talent management. Bogota: Mc Graw Hill.

David, F. (2013). Concepts of Strategic Management. Mexico: PEARSON. Directives ISO / IEC Part 2. (2007). Occupational Health and Safety Management System. Requirements Geneva: ISO copyright office.

Fontalvo, T., \& Vergara, J. (2010). Quality management in the ISO 9001: 2008 services. Santa fe de Bogotá: Asesores 2000 editions.
García, J., Jiménez, F., Arnaud, M., Tapia, Y., \& Lino, L. (2011). Introduction to the Methodology of Research in Health Sciences. Mexico: MCGRAWHILL INTERAMERICANA EDITORS.

Gimeno, J., Repullo, J., \& Rubio, S. (2006). Health systems and services. Madrid: Editions. Diaz de Santos.

Griful, E., \& Canela, MA (2005). Quality management. Barcelona, Spain: UPS Editions.

IAEA, International Atomic Energy Agency. (2009). Audits in Quality Management in Nuclear Medicine practices. Vienna: IAEA Publications.

IAEA. (2015). Quality Management Audits in Nuclear Medicine Practices. Vienna: Marketing and Sales Unit, Publishing Section.

Nuclear Safety Council. (2011). Criteria for discharge of patients and measures for the radiological protection of the public after metabolic treatments with iodine 131. Madrid: Publications CSN / SEPR / SEFM.

Nuclear Safety Council. (2011). Criteria for discharge of patients and measures for the radiological protection of the public after metabolic treatments with iodine 131. Madrid: Publications CSN / SEPR / SEFM.

Technical Committee ISO / TC 176, Management Quality Assurance and Subcommittee SC 3, Support Technologies. (2011). Guidelines for the audit of Management Systems. Geneva: ISO copyright office.

Technical Committee ISO / TC 176. (2008). Quality management system - Requirements. Geneva: ISO copyright office.

Technical Committee ISO / TC 207, Environmental Management, Subcommittee SC1, Environmental Management Systems. (2004). ISO 14001 Environmental Management Systems Requirements with guidance for their use. Switzerland: ISO copyright office.

\section{How to cite this article:}

Carlos Enrique Novillo Yaguarshungo, Ángel Rigoberto Guamán Mendoza, Jacinto Eduardo Villota Moscoso and José Luis Gavidia García. 2018. Technical Methodology for an Integrated System of Quality, Safety and Environment Management in the Hospital Nuclear Medicine Unit, Teodoro Maldonado Carbo De GuayaquilEcuador. Int.J.Curr.Res.Aca.Rev. 6(9), 23-33. doi: https://doi.org/10.20546/ijcrar.2018.609.004 